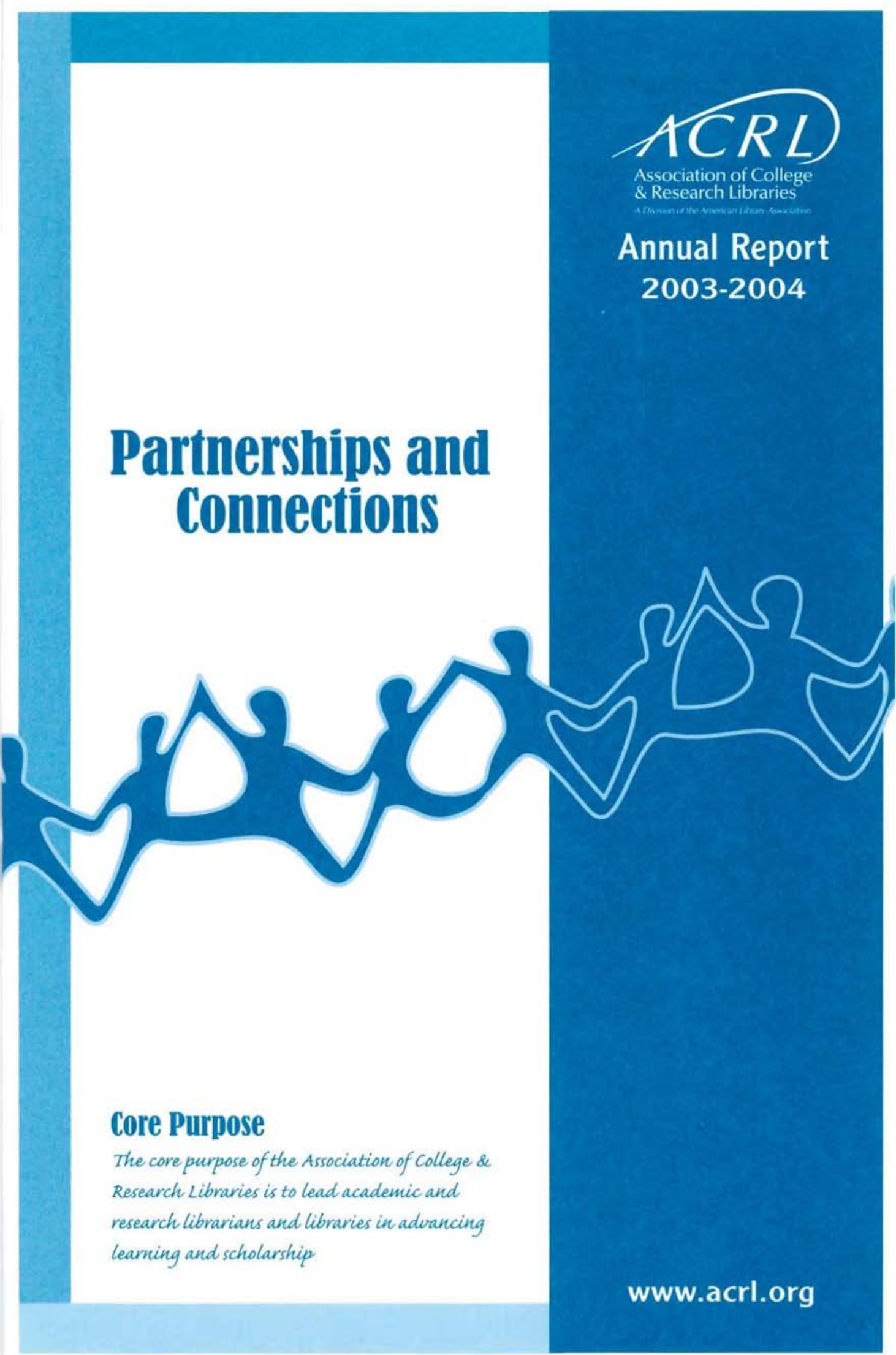




\section{Message from the President}

\section{Tyrone H. Cannon \\ ACRL's 65th President}

Colleagues, thank you for the wonderful opportunity to serve as ACRL President for 2003-04. It has been a year of accomplishment, reflection, and challenge for ACRL. My trips to many of our chapters gave me great pride in being an academic librarian, and it was gratifying to see firsthand the wonderful "Partnerships and Connections"

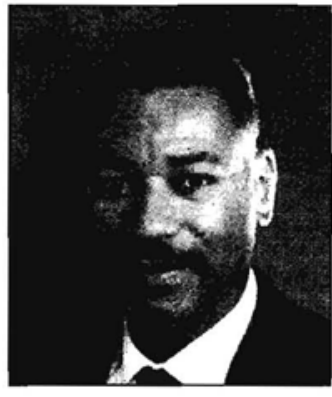
that we have established with our colleagues to ensure competence in information literacy and lifelong learning. It was an honor to work with the ACRL Board, staff, and members to develop a new strategic plan for the association. I am confident that "Charting our Future: ACRL Strategic Plan 2020" will result in ACRL being responsible and universally recognized for positioning academic and research librarians and libraries as indispensable in advancing learning and scholarship.

In addition to the development of the new strategic plan, members and leaders further contributed to the growth of ACRL through participation in several task forces created in response to member needs and issues (Task Force on National Advocacy, Long-Term Investment Task Force, First-Year Experience Task Force, and Annual Conference Program Funding Task Force). The Marketing Academic and Research Libraries Committee was also created to focus on ways to implement the Academic and Research Library@your library campaign. Twenty-eight programs presented by ACRL sections and committees provided learning and sharing opportunities specific to academic and research librarians at the 2004 ALA Annual Conference. In particular, ACRL's President's Program, "Prenuptials, Marriage, and In-Laws" explored the innovative collaborations in place from several innovative and assessment-based viewpoints. ACRL also expanded its reach by presenting two programs and leading a roundtable discussion at the American Association of Higher Education's annual conference.

Congratulations to all ACRL award winners - libraries and individuals. I was pleased to present the ACRL Excellence in Academic Libraries Awards to Richland College, Hope College, and the University of Washington. Tom Kirk (Earlham College) was named Academic/Research Librarian of the Year.

In closing, I want to express very special thanks to ACRL Executive Director Mary Ellen K. Davis, the ACRL staff, the ACRL Board, and members for their hard work, creativity, flexibility, and sense of humor. These dedicated individuals equally share the accomplishments of this year. 


\section{ACRL Sponsorships}

\section{ACRL Sponsorships for 2004}

ACRL expresses its sincere appreciation to the following sponsors for their generous donations to the various programs and events we have offered throughout the year. Thanks to your corporate support, ACRL members benefitted from enhanced programs and services this year.

\section{Colleagues}

\section{Summa Cum Laude}

Blackwell's Book Services

ProQuest

\section{Magna Cum Laude}

YBP Library Services

\section{Cum Laude}

Antiquarian Booksellers Association of America

Aux Amateurs de Livres International Belser Wissenschaftlicher Dienst Coutts Nijhoff International EBSCO Information Services

Gale Group (Thomson)

Iberbook International

IDC Publishers

Innovative Interfaces

The Lewis Walpole Library at Yale

University

Thomson Scientific

\section{Dean's List}

Adam Matthew Publications

Brepols Publishers

Cambridge Scientific Abstracts

Casalini Libri

CQ Press

Elsevier

Elsevier Science on behalf of its journal Research Strategies

Erasmus Boekhandel

Goethe Institut
Greenwood Publishing Group

Harald Fischer Verlag

The Haworth Press

Jean Touzot Libraire-Editeur

John Wiley \& Sons

K. G. Saur Verlag

Lindsay \& Howes Booksellers

Otto Harrassowitz

Puvill Libros

Sirsi Corporation

\section{Mortar Board}

Association of Research Libraries

Bauman Rare Books

Bibliographical Society of America

Bruce McKittrick Rare Books

Charles B. Wood, III, Antiquarian

Booksellers

Lexis Nexis

Marilyn Braiterman Antiquarian

Bookseller

McGowan Book Company

The 19th Century Shop

PBA Galleries

The Philadelphia Rare Books and Manuscripts Company

Phillip J. Pirages Fine Books and

Manuscripts

Priscilla Juvelis

Randall House

Reese Company

Springer

Stroud Booksellers

Swann Galleries 


\section{Message from the Vice-President}

\section{Frances Maloy}

Vice-President/President-Elect

I am pleased to report on my activities for the FY04 year as your vice president. It has truly been a pleasure serving the association as vice president-the opportunity to interact with academic librarians, share ideas and common concerns, and advance my leadership skills far outweigh the added workload and responsibili-

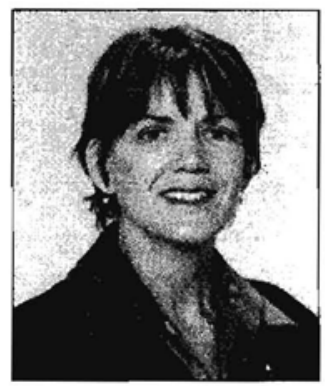
ties associated with the role. I am indebted to my Vice Provost and Director of Libraries Linda Mathews, my colleagues, and staff at Emory University for their support and encouragement during my term. Their ideas, advice, and support made it possible for me to fulfill my duties as an ACRL officer.

My Appointments Committee, co-chaired by Linda Brown (Bowling Green State University) and Suzy Tarba (Wesleyan University) did an excellent job of appointing new faces to ACRL committees. In response to concerns from new and junior members of ACRL, I made it my priority to appoint as many new people to committees as possible, so that we may grow the expertise and leadership in the association. Participation on ACRL committees is a vital part of developing new leaders and, as our profession ages, this is critically important for us all.

The Nominating Committee fulfilled its role in creating an excellent slate of two highly qualified candidates for ACRL President. I am excited about the possibility of either Randy Burke Hensley (University of Hawaii) or Pamela Snelson (Franklin \& Marshall College) assuming the role of vice-president/president-elect and hope that you will engage them in conversations about your needs and ideas for the future of ACRL and academic and research librarians.

My President's Program Committee, co-chaired by Jane Treadwell (University of Illinois-Springfield) and Victoria Hannawalt (Reed College), has developed an exciting program for Annual Conference 2005 in Chicago. The title is "Time for a reality check: Academic librarians in a Tivo $($ lutionary age." The speakers include, Tom McBride (Keefer Professor of the Humanities at Beloit College in Wisconsin) and Ron Nief (director of public relations at Beloit), co-editors of the Beloit College Mindset List. Also presenting is David Silver, an assistant professor in the Department of Communications at the University of Washington-Seattle and a specialist in cyberculture.

Finally, I wish to thank Tyrone Cannon for his leadership in developing the strategic plan for the association. Using the plan as a guide, we will break new ground in meeting your expressed needs as librarians and ensuring the long-term sustainability of the association. Your input and ideas are critical to the success of this phase of the plan. The Board and ACRL staff will also be working with sections and committees to ask them to take 
responsibility for enacting specific programs set forth in the plan. 1 also expect to be appointing several new task forces to work on specific areas of the plan. As president, I will work with the Board to review association processes and structure with goals of making ACRL more streamlined and less bureaucratic and instituting the values set forth in the plan.

This past year has been extremely exciting and busy. 1 thank you so much for the opportunity to serve you in this role.

\section{ACRL 2004 Annual Conference Programs-Orlando}

-ACRL Presidents' Program—Prenuptials, Marriage, and In-laws: Partnerships and ConnectionsThe Leaming Community as Knowledge Builders

- AAMES - Impact of Technology on Asian African and Middle Eastern Collections

- ACRLAASL-My First-Year Student is Your Senior: Bridging the Gap Between High School and College/University Information Literacy Initiatives

- ANSS-Her Eyes Were Watching Humanity: Zora Neale Hurston as Ethnographer, Novelist, and Feminist

- ARTS - Drawing on Fantasy: Services and Collections for Animation

- (a) your library-Marketing Your Academic or Research Library: The Good, the Bad, and the Useful

- CLS-A Library Balancing Act: Patron Rights vs. National Security

- CJCLS - Bridging the Gap: How Well Are We Serving Our Students' Needs as They Move Along in Their Learning Careers?

- Copyright Committee — Copyright Basics for the Digital World

- DLS - Interlibrary Cooperation and Resource Sharing to Better Serve Distributed Leamers

- EBSS - Pedagogy and the Online Learner

- Ethics Committee-Ethics Instruction in Library and Information Science Schools

w IS - The Pride of Success: Affording Information Literacy in an Uncertain Academic Economy

- IS-Wrestling with Research: A Half-Day Workshop on Conducting Instruction-Related Research

- Intellectual Freedom Committee-Community Use, Community Pressure, and Intellectual Freedom: Do Academic Libraries Need to Worry?

- LES - Cuban Voices, English Words: Language and Identity in Cuban-American Literature

- LPSS-Interactive and Collaborative Curricular Learning Communities

- Membership Committee _ Beating the Bushes: Recruiting a New Generation of Academic Librarians

- New Publications Board-Get Us to the Press on Time: A Discussion Forum on the Preparation of the Monograph

- Racial \& Ethnic Diversity—Attracting Minority Librarians to Academic Libraries

- RBMS-Documenting Cultural Communities in Florida

- Scholarly Communication Committee-Trust and Antitrust: Responding to Consolidation in the Journal Publishing Industry

w SEES - Library Catalogs and Non-Roman Scripts: Development and Implementation of Unicode for Cataloging and Public Access

- SEES-The Square-Peg Problem: Special Handling in a Streamlined World

- STS-Making Connections on Campus: Collaborative Approaches to Information Literacy in the Sciences

- ULS-Beyond the MLS: Today's Graduates and Tomorrow's Academic Libraries

- WESS - Scholarly Communication in Europe:Trends in Libraries, Publishing, and Copyright

- WSS-Telling Our Stories Now: Women's Archives in the Digital Age 


\section{Letter from the Executive Director}

\section{Mary Ellen K. Davis}

\section{Executive Director}

One of the rewards of developing a strategic plan is the opportunity it provides to learn more about your needs, the needs of your libraries, issues facing the profession, and how the association might help you meet these challenges. The ACRL Board took every opportunity to listen to a wide range of views on the profes-

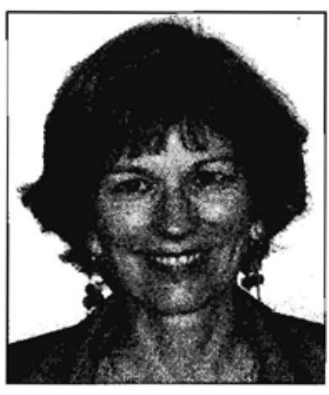
sion and the association as part of the strategic planning process.

From our research (which included focus groups, telephone interviews, a Web-based survey open to all ACRL members, and regular conversations with members at the ACRL leadership council at the Midwinter Meeting and Annual Conference) we learned that the issues/challenges facing libraries include the impact of expanding technology, intellectual property, customer service, the changing role of librarians, collaborations/partnerships, leadership/management, and assessment.

We learned that you see a broadly defined role for ACRL that includes focus on professional development, advancing the profession, and advocacy. As one respondent said, "Survival is our challenge. Why do we need a library? What is our relevance?"

We also learned that you value ACRL's programs and services, especially its publications and its professional development opportunities.

You also value the professional community that ACRL provides. As one respondent put it, "ACRL is all about creating a community for us (academic librarians). A personal relationship with individual members is so important."

At the 2004 Annual Conference, the ACRL Board approved the results of this planning process in the form of a new strategic plan: "Charting Our Future: ACRL Strategic Plan 2020.” (http://www.ala.org/ala/acrl/abouta$\mathrm{crl} /$ whatisacrl/acrlstratplan/stratplan.htm)

This plan addresses the top issues and challenges that you identified while refocusing ACRL on its core purpose, "To lead academic and research librarians and libraries in advancing learning and scholarship."

ACRL members and staff will also be working to embody the core values identified in the plan:

- ACRL has visionary leadership and is open to change, new ideas, and global perspectives;

- ACRL is committed to service to members;

- ACRL is committed to integrity and transparency;

- ACRL is committed to diversity of people and ideas;

- ACRL is committed to continuous learning; and

- ACRL is dedicated to the values of higher education, to intellectual freedom, and to upholding "The Library Bill of Rights." 
I want to thank everyone for sharing their thoughts, ideas, and hopes as we moved through the strategic planning process. I also want to thank the ACRL Board who devoted many extra days and nights to developing a new strategic plan for ACRL. Special thanks to ACRL President Tyrone Cannon for his leadership in this endeavor.

I also want to acknowledge the generous support provided by ACRL's many corporate colleagues and Friends. Finally, thank you to the ACRL staff who, working together with our members, helped ACRL accomplish the many activities that you will read about in this report.

\section{Services and programs}

ACRL continued to offer a wide range of high-quality programs and services, which are highlighted in this report. In addition, ACRL staff and leaders are frequently contacted for referrals, information on faculty status, ACRL standards and guidelines, evaluating libraries, information regarding new technologies, scholarly communication, and information literacy.

\section{Strategic plan}

A major focus of the association in 2003-04 was the creation of a new strategic plan to guide the future growth and direction of ACRL. The Board of Directors spent a significant amount of time receiving data gathered from the members and crafting the new strategic plan. "Charting our Future: ACRL Strategic Plan 2020," approved at the ALA Annual Conference in June, will provide an integrated and ongoing process for thinking and planning that will guide the association for the next five to ten years.

ACRL engaged Tecker Consultants to lead a strategic planning process, which included extensive interaction with ACRL members, leaders, nonmembers, and staff to gauge the present state of the academic and research library profession, the role of $A C R L$ within that community, and implications for the future.

The approach used in this planning process was designed to help ACRL develop strategies across four planning horizons: action planning (one-totwo years out), strategic planning (three-to-five years out), critical factors (five-to-ten years out), and envisioned future (ten-to-thirty years out). The ultimate goal was to develop a strategic plan that would not only provide ACRL with a road map for the near future, but prepare the association for changes in the long term. An important part of this was the development of mega-issues - issues of strategic importance that represent challenges the organization will need to address.

\section{Recruitment to the profession}

To address growing concerns about recruitment to the profession, the ACRL/Association of Research Libraries joint task force developed a short recruitment video, which features academic librarians talking about what they do and why they made their career choices. The video is available 


\section{Year in Review}

in a variety of formats, including live streaming video, downloadable zip file, and VHS/DVD. The streaming video and zip file are available on the ACRL Web site (www.ala.org/acrl, Issues \& Advocacy, Recruiting to the Profession). This video was screened in three venues at the ALA Annual Conference (the ALA Public Awareness Committee meeting, the ACRL Leadership Council, and the ALA Recruitment Assembly).

\section{Advocacy and government relations}

To further ACRL's advocacy efforts, ACRL has continued to work on the @ your library campaign for academic and research libraries. A new standing committee for marketing was created this year. To help librarians more effectively communicate the value of libraries and librarians, this new committee offered a full-day workshop entitled "Creating a Marketing Plan for Your Academic and Research Library," during the ALA Midwinter Meeting in San Diego. It also offered a 2004 Annual Conference Program entitled "Marketing Your Academic or Research Library: The Good, the Bad, and the Useful."

As part of ACRL's advocacy awareness, ACRL continued placing ads in

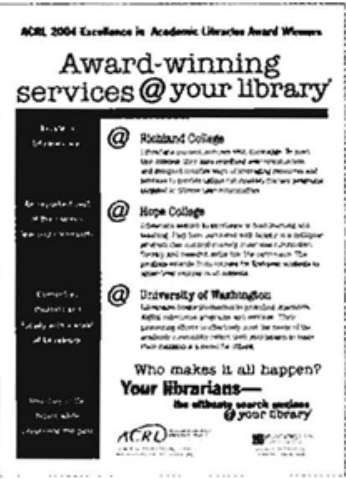
the Chronicle of Higher Education (October 24 and November 14, 2003, and April 2, 2004), focusing on the contributions libraries make to the campus learning community. Two of the ads featured quotes from administrators, faculty, and students; the third recognized the 2004 Excellence in Academic Libraries award winners.

In legislative news, ACRL adopted the 2003-04 Legislative Agenda, which focused on several legislative and public policy areas that affect academic libraries. The "ACRL Legislative Update," designed to keep members up-to-date about the status of legislation and other public policy issues that affect academic libraries, is sent to members twice a month. At ALA's Legislative Day, ACRL sponsored a luncheon for academic librarians. Emily Sheketoff of the ALA Washington Office and Mark Smith of the American Association of University Professors spoke on several legislative issues that affect academic and research libraries and offered tips on being an effective advocate. To help in the fight against the USA PATRIOT Act, ACRL held a PATRIOT Act session for academic librarians at the 2004 Midwinter Meeting.

ACRL, along with ALA's Office for Information Technology Policy, the Association of Research Libraries, the Association of American Law Libraries, the Medical Library Association, and the Special Libraries Association, endorsed and released a "Statement on Fair Use and Electronic Reserves," in response to confusion about the TEACH Act and ongoing uncertainty regarding e-reserves and fair use. ACRL also reviewed federal law enforcement's petition to the FCC to expand the coverage of the Communication Assistance for Law Enforcement Act (CALEA) and signed on to commentary from the higher education community opposing such expan- 


\section{Year in Review}

sion. ACRL worked with ALA's Public Information Office to develop a press release about this with a quote from ACRL President Tyrone Cannon, which appeared in the Chronicle of Higher Education article, "Colleges Fear that Agencies' Surveillance Request Will Require Expensive Network Changes," on April 14, 2004.

\section{Awards}

Since 1923, the ACRL Awards Program has recognized and honored the professional contributions and achievements of academic and research libraries and librarians. This special recognition by ACRL enhances the sense of personal growth and accomplishment of our members, provides our membership with role models, and strengthens the image of our membership in the eyes of employers, leadership, and the academic community as a whole. In 2004, 25 outstanding individuals and institutions received ACRL awards recognizing their accomplishments. ACRL's top honor, the Academic/Research Librarian of the Year Award, was presented to Tom Kirk, library director and coordinator of information services at the Lilly Library of Earlham College, for his dedication as an outstanding member of the library profession who has made a significant contribution to academic librarianship and library development.

ACRL continues to present the Excellence in Academic Libraries Award to recognize the staff of a community college, a college, and a university library for exemplary programs that deliver outstanding services and resources to further the educational mission of their institution. This year's recipients were Richland College, Hope College and the University of Washington. The award, sponsored by ACRL and Blackwell's Book Services, includes a presentation ceremony on the campus of the awardwinning library.

\section{Chapters}

ACRL extends its reach into the local academic library community through the activities of its chapters. Offering opportunities for academic librarians to meet and share experiences in their regions, ACRL chapters sponsored more than 40 programs across the United States, and ACRL officers visited chapters in Missouri, Michigan, Nebraska, Maryland, and California as guest speakers.

In March, the University of Illinois at Urbana-Champaign (UIUC) Student Chapter of ALA voted to accept a new constitution and adopt a new bylaws allowing for the formation of student divisions. Immediately following the announcement of the adoption of these governing documents, the UIUC ACRL Divisional Interest Committee presented a petition to the UIUC Board requesting the formation of a student division of ACRL. The Board accepted the petition, and there is now a student chapter of ACRL at the UIUC Graduate School of Library and Information Science. 


\section{ACRL Award Winners 2004}

Academic/Research Librarian of the Year (Donor: YBP Library Services) Tom Kirk, Earlham College

- ACRLDLS Haworth Press Distance Learning Librarian Conference Sponsorship Award

(Donor: Haworth Press, Inc.) Susan S. Lowe, University of Maine System

a Hugh C. Atkinson Memorial Award

(Donor: ACRL, ALCTS, LAMA, LITA) Jerome Yavarkovsky, Boston College

- Doctoral Dissertation Fellowship

(Donor: Thomson Scientific) Judy Jeng, Rutgers University for "Usability of Digital Library: An Evaluation Model"

- Excellence in Academic Libraries

(Donor: Blackwell's Book Services)

Community College: Richland College

College: Hope College

University: University of Washington

- Samuel Lazerow Fellowship (Donor: Thomson Scientific) Karen M. Letarte and Jacqueline P. Samples, both of North Carolina State University for their research proposal entitled "Looking at FRBR Through Users' Eyes: Toward Improved Catalog Displays for Electronic Serials ${ }^{n}$

- CJCLS Awards (Donor: EBSCO Information Services) Learning Resources/Leadership Program Award: Carolyn Norman, California Community Colleges, Office of the Chancellor Library Program Achievement Award: Janice Peyton and Lonna Beers, both of the North Harris Montgomery Community College District

- Coutts Nijhoff International West European Specialist Study Grant

(Donor: Coutts Nijhoff International)

Helene S. Baumann, Duke University

- EBSS Distinguished Education and Behavior Sciences Librarian

(Donor: John Wiley \& Sons, Inc.) Laurene E. Zaporozhetz, Murray State University

\section{- IS Awards}

Miriam Dudley Award (Donor: Elsevier Science): William Miller, Florida Atlantic University

Publication Award (two awards): Esther Stampfer Grassian and Joan Kaplowitz, both of UCLA

Ann J. Grafstein, Hofstra University

- LPSS/Marta Lange Award (Donor: $C Q$ Press) Lucia Snowhill, University of California-Santa Barbara

- RBMS/Leab Exhibition Catalogue Awards (Donor: Katharine Kyes and Daniel J. Leab Endowment)

CATEGORY 1 (EXPENSIVE): Elizabeth I: Then and Now, by Georgiana Ziegler, compiler, and submitted by the Folger Shakespeare Library

CATEgORY 2 (MODERATELY EXPENSIVE): Bruce Peel Special Collections Library of the University of Alberta Libraries, First Impressions: The Fledgling Years of the Black Sparrow press 1966-1970, by Professor Michael O'Driscoll, et al.

CATEgory 3 (INEXPENSIVE): The Auroral Light: Photographs by Women from Grolier Club Member Collections, by Anne H. Hoy and Kimball Higgs, from The Grolier Club CATEGORY 4 (BROCHUAES): Getty Research Institute's brochure, Robert Motherwell: A la pintura/To Painting

CATEGORY 5 (ELECTRONIC EXHIBITIONS): Bancroft Library of the University of California, The California Grizzly at the Bancroft Library, http://bancroft.berkeley.edu/Exhibits/bearinmind

wSS Achievement in Women's Studies Librarianship Awards

Career Achievement (Donor: Greenwood Publishing Group): Phyllis Holman Weisbard, University of Wisconsin Madison

Significant Achievement (Donor: Routledge): Donna Roe, University of Detroit Mercy 
Seventeen sections provide members with opportunities to advance the knowledge base of the profession, develop leadership skills, mentor colleagues, and share their expertise and ideas. Sections also develop and maintain standards and guidelines for directing the development and future direction of the profession.

Sections offered 18 stimulating programs and 1 preconference at the ALA Annual Conference in Orlando on issues relating to the creation, collection, preservation, access, and exchange of information; recruiting new and diverse talent to academic and research librarianship; scholarly communication; copyright; ethics; information literacy; and partnerships. Eight ACRL programs at the ALA Annual Conference in Orlando were selected by Library Journal (June 1, 2004) as having "the most promise to educate, inform, excite, and entertain." Six additional programs received stars indicating that the topic and/or speakers were of "the highest importance or have the greatest potential."

The College Libraries Section held virtual meetings in lieu of holding sessions at ALA's Midwinter Meeting. The Instruction Section worked to redesign the information literacy Web site to offer improved access to a wide range of information literacy resources and coordinate access to the information literacy pages offered by ACRL. The Law and Political Science Section sponsored Political Information Day @ your library on Election Day, November 4, 2003. The Rare Books and Manuscripts Section and the ALA Office for Diversity drafted a marketing letter that will be

\section{ACRL Membership Statistics}

\begin{tabular}{lrrrrr}
$\begin{array}{l}\text { ACRL } \\
\text { Sections }\end{array}$ & Personal & Organizational & $\begin{array}{r}\text { August 2004 } \\
\text { total }\end{array}$ & $\begin{array}{r}\text { August 2004 } \\
\text { total }\end{array}$ & Change \\
\hline ACRL & 11.279 & 881 & 12.190 & 12.174 & $0.13 \%$ \\
\hline AAMES & 344 & 53 & 398 & 381 & $4.46 \%$ \\
\hline AFAS & 238 & 18 & 256 & 254 & $0.79 \%$ \\
\hline ANSS & 420 & 56 & 476 & 485 & $-1.86 \%$ \\
\hline ARTS & 712 & 72 & 784 & 789 & $-0.63 \%$ \\
\hline CJCLS & 1.059 & 193 & 1255 & 1.235 & $1.62 \%$ \\
\hline CLS & 2.193 & 236 & 2.433 & 2.427 & $0.25 \%$ \\
\hline DLS & 1.421 & 72 & 1.494 & 1.509 & $-0.99 \%$ \\
EBSS & 770 & 141 & 911 & 930 & $-2.04 \%$ \\
\hline IS & 3.600 & 334 & 3.934 & 3.919 & $0.38 \%$ \\
\hline LES & 552 & 13 & 565 & 558 & $1.25 \%$ \\
LPSS & 529 & 68 & 598 & 584 & $2.40 \%$ \\
RBMS & 1.492 & 135 & 1.628 & 1.617 & $0.68 \%$ \\
\hline SEES & 175 & 38 & 215 & 219 & $-1.83 \%$ \\
\hline STS & 1.353 & 165 & 1.519 & 1.569 & $-3.19 \%$ \\
\hline ULS & 4.804 & 246 & 5.054 & 5.141 & $-1.69 \%$ \\
WESS & 541 & 41 & 586 & 565 & $3.72 \%$ \\
\hline
\end{tabular}




\section{Year in Review}

sent to Master's programs in Ethnic Studies to recruit students to the field of special collections librarianship. For the first time since 1988, ACRL's Western European Studies Section (WESS) offered a conference abroad. The WESS European Conference "Migrations in Society, Culture, and the Library" was held in Paris, France, March 22-26, 2004.

\section{Standards and guidelines}

ACRL is the source that the higher education community looks to for standards and guidelines on academic libraries. The association promulgates standards and guidelines to help libraries, academic institutions, and accrediting agencies understand the elements of a high-quality library. ACRL has created a total of 27 standards, guidelines, and model statements that are reviewed and updated by the membership on a regular basis. All of ACRL's standards and guidelines are posted on the ACRL Web site (www. ala.org/acrl, click on "Standards and Guidelines.")

Newly approved standards for 2004 include "Standards for Libraries in Higher Education," a comprehensive standard that applies to all academic libraries and replaces the standards for college, university, and community, junior, and technical learning resources programs. Other revisions that were approved are "Guidelines for Distance Learning Library Services," "Guidelines for the Interlibrary Loan of Rare and Unique Materials," and "Guideline for the Screening and Appointment of Academic Librarians Using a Search Committee."

\section{Partnerships and collaborations}

ACRL collaborated with the higher education community in a variety of ways to define and illustrate the role of libraries in learning, teaching, and research.

Over the course of the year, the ACRL executive director met to discuss possible areas for future collaboration with the leaders of a number of higher education-related organizations, including the American Association for Higher Education, the Appalachian College Association, the Council for Independent Colleges, the American Psychological Association, the Association of Research Libraries, the TLT Group, and the University Continuing Education Association.

ACRL provided programming at the American Association for Higher Education Annual Conference in April. ACRL President Tyrone Cannon and members Jon Cawthorne and Connie Dowell, along with a University of California-San Diego student, gave a presentation on the student-centered library; the ACRL president and executive director presented, "The Lone Ranger is Dead," outlining the growing need for collaborative partnerships between libraries and other campus units; and an ACRL member facilitated a round table session on the ethical use of information. 


\section{Year in Review}

ACRL members also made presentations at the National Resource Center's Annual Conference on the First-Year Experience and Students in Transition in February.

\section{Scholarly communication}

Open access took center stage in FY04 as a variety of activities focused on the issue. ACRL staff drafted a white paper on open access and its relationship to ACRL serial publications. The report is available on the ACRL Web site (www.ala.org/acrl, Issues \& Advocacy, Scholarly Communication). The Scholarly Communication Committee collaborated with the Scholarly Publishing and Academic Resources Coalition (SPARC) and Association of Research Libraries (ARL) in the development of an

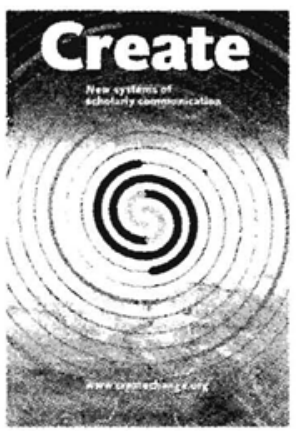
open access brochure as well as a new version of the Create Change brochure. The ACRL/SPARC Forum in Orlando was entitled "Scholarly Communication in the Humanities: Does Open Access Apply?" The program, which built on the very successful open access forum at the Midwinter Meeting in San Diego, attracted an attendance of approximately 200 and was very well received. The Scholarly Communication Discussion Group also coordinated discussion programs related to the forum.

A full-day preconference titled "Scholarly Communication 101 ," was offered at the 2004 Annual Conference in Orlando. More than 50 people attended the preconference, which was designed to broaden the base of academic librarians who are familiar with scholarly communication issues. Evaluations of the preconference were uniformly excellent. In Orlando, two programs on the issue of scholarly communication were also presented and well-received (the Scholarly Communication Committee's "Trust and Antitrust: Responding to Consolidation in the Journal Publishing Industry" and WESS's "Scholarly Communication in Europe: Trends in Libraries, Publishing, and Copyright").

ACRL's advocacy efforts were also at work in the area of scholarly communication. ACRL participated actively in the Open Access Working Group, an alliance of major U.S. library associations and public interest groups that is advocating change in federal policy related to open access. The group focused most of its efforts during the year on the recent proposal for enhanced public access to articles documenting the results of research funded by the National Institutes of Health (NIH). ACRL sent an open letter to NIH in support of the proposal. To that same end, a letter was also sent to NIH on behalf of ALA, ACRL, ARL, SPARC, the Association of Academic Health Sciences Libraries, and the Medial Library Association. Another letter, sent on behalf of ALA, ACRL, ARL, SPARC, the American Association of Law Libraries, the AAHSL, Public Knowledge, and the MLA, was sent to the Science and Technology Committee of the UK parliament in response to its inquiry into scientific, technical, and medical publishing. 


\section{Year in Review}

The Scholarly Communication Committee issued an "ACRL Scholarly Communications Research Agenda" and encouraged ACRL members to do research on the topics it covers. The committee also coordinated the ongoing bimonthly column on scholarly communication for C\&RL News.

\section{Information literacy}

ACRL continues to expand on its work in the area of information literacy and promote related standards. The Council of Independent Colleges endorsed the "Information Literacy Competency Standards for Higher

\section{Information Literacy}

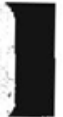
Education" in February 2004, and the ACRL Executive Committee approved the Council of Australian University Librarians' application

to adapt the ACRL statement "Characteristics of Programs of Information Literacy that Illustrate Best Practices: A Guideline" for Australian universities.

ACRL's information literacy Web site has been redesigned to offer a more user-friendly interface for access to a wide range of information literacy resources and to coordinate access to the variety of information literacy pages offered by ACRL.

ACRL has continued its partnership with TLT Group to offer a three-part online seminar series on the topic of information literacy and began offering an ACRL online seminar, "Assessing Student Learning Outcomes."

\section{Professional development}

Continuous learning is very important to the ACRL membership. To meet this ongoing need, ACRL offered a varied slate of professional development activities. During 2003-04, more than 1,500 individuals participated in preconferences, workshops, institutes, and e-learning opportunities, which covered a variety of topics, such as scholarly communication, information literacy, marketing, and collaboration. Three workshops were offered at the ALA Midwinter Meeting to expand opportunities for participation. To broaden the participation of new and/or minority librarians, ACRL provided more than $\$ 14,980$ in scholarship funds to 24 participants in the IIL Immersion Program and 11 scholarships ( 7 full, 4 partial) to participants in the Rare Books and Manuscripts Section Preconference.

\section{National Conference}

In 2003-04, ACRL members worked with staff to finalize arrangements for the 12th National Conference. ACRL's 12th National Conference, "Currents and Convergence: Navigating the Rivers of Change," will be held in Minneapolis, April 7-10, 2005. Camila Alire (University of New Mexico) will chair the conference. 


\section{Year in Review}

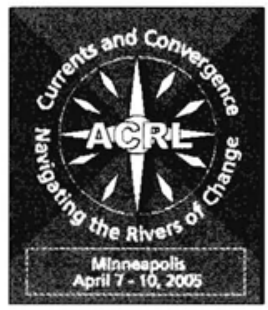

Major planning activities included selecting speakers, issuing the call for presenters, selecting programs, launching the call for exhibitors, and opening online housing and registration. Seven in-depth preconferences have been developed on topics such as assessment, information literacy, leadership, and marketing. Special events, tours, and additional networking opportunities have also been identified. For the first time ever, ACRL will be offering a virtual component to the National Conference in 2005. Bookmark www.acrl.org /minneapolis!

\section{Institute for Information Literacy (IIL) Immersion Programs}

To help librarians and institutions develop and implement information literacy programs on their campuses, ACRL's Institute for Information Literacy offered both a regional and national Immersion Program. These four-and-a-half day programs provided two tracks of intensive training and education.

Track 1 focused on individual development for librarians interested in enhancing or extending their individual instruction skills while Track 2 focused on developing, integrating, or managing institutional and programmatic information literacy programs.

This year, ACRL licensed the Immersion Program to Southern California Instruction Librarians (sCIL), an interest group of the California Academic and Research Libraries. Fifty-eight individuals participated in the regional Immersion Program, held at Claremont Colleges

- "Not only was my understanding of information literacy concepts and practices deepened, but I was able to spend concentrated time and effort exploring ways to move our program forward. My work was informed by highly relevant sessions led by the ACRL Immersion faculty - who are not only practitioners, but excellent teachers and leaders in the field of Information literacy. I've returned to my university full of ideas and with an action plan in hand!"

- "Immersion was an unforgettable experience that inspired me to reflect upon my own teaching pedagogy and create a repertoire from which to build to improve my skills. The Immersion faculty are clearly experts in their field, with a passion for passing on their knowledge. I would highly recommend all librarians with instruction responsibilities to attend the program."

----Immersion participants in Claremont, California, July 22-27, 2004. Eighty-eight individuals took part in the national Immersion Program, held at the University of Washington-Seattle, July 30-August 4, 2004. 


\section{Year in Review}

\section{Leadership institutes}

Another very successful ACRL/Harvard Leadership Institute was held in Cambridge, Massachusetts, August 8-13,2004. The institute was full with 90 registrants and a waiting list. Harvard Institutes for Higher Education faculty gave special attention to issues such as leadership, organizational strategy, transformational learning, and planning. Alumni reunions were held at both the ALA Midwinter Meeting and Annual Conference in special presentations from Harvard faculty.

\section{WESS European Conference}

One hundred sixteen individuals attended ACRL's Western European Studies Section's (WESS) "Migrations in Society, Culture, and the Library" in Paris, France, March 22-26, 2004. Conference sessions were held at Bibliothèque Nationale de France (BNF), the Salon du Livre at the Porte de Versailles, and the Espace Georges Bernanos. Program sessions were augmented by special events, including receptions at the BNF and City Hall, dinner at the Eiffel Tower, and a tour of the Centre Culturel Calouste Gulbenkian.

\section{E-learning}

ACRL launched two new online seminars in FY2004. "Assessing Student Learning Outcomes" was offered three times, beginning in fall 2003. It covers planning for assessment, using the "Information Literacy Competency Standards for Higher Education," developing goals and objectives, and developing a research design. "Electronic Collection Development for the Academic e-Library" was offered for the first time in August 2004.

\section{Workshops and preconferences}

Due to their popularity, ACRL offered workshops prior to the ALA Midwinter Meeting for the third time. These workshops continue to be well-received, with a total of 181 individuals attending in San Diego:

- Information Commons 101: Nuts and Bolts Planning

- Information Literacy Across the Curriculum

- Creating a Marketing Plan for Your Library

ACRL preconferences, held in conjunction with the ALA Annual Conference, continue to provide academic and research librarians with tips, tools, and new ways of thinking. Four preconferences were held before the ALA Annual Conference in Orlando, with 571 individuals participating:

- 45th Annual Rare Books and Manuscripts Preconference, Ebb and Flow: The Migration of Collections to American Libraries

- Information Commons 101: Nuts and Bolts Planning

- Information Literacy - Time for a Comprehensive Plan

- Scholarly Communications 101 


\section{Year in Review}

Participants learn to create an academic e-library collection development plan for free and fee-based Web-accessible resources for a patron community of their choice. "All Users Are Local," ACRL's online seminar on distance learning library services,

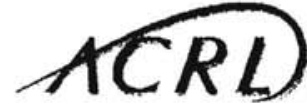

Online Education

Assessing Student Learning Outcomes was offered twice during the year as well. Online seminars feature real-time chat discussions, threaded discussion lists, and 24/7 access to course materials. Seminars continue to be well-received with 99 percent of respondents agreeing that their time in the seminars was well spent and 85 percent rating the quality of the seminars as stimulating or above average.

ACRL has continued its partnership with TLT Group to offer a three-part online seminar series on information literacy. The series includes seminars on best practices, collaboration, and assessment.

\section{Publications}

In 2004, ACRL published two new titles, plus three volumes of the 2002 statistics and three volumes of the 2003 academic library statistics on an accelerated schedule. Staff prepared a white paper that considered the effects of moving its four serials (C\&RL, C\&RL News, CHOICE, and RBM) to open access models.

\section{CHOICE}

In March, CHOICE published a special anniversary issue celebrating its 40th year of continuous publication. Today, some four decades after the appearance of the first issue of CHOICE in March 1964, CHOICE's primary mission is much the same as described by Richard Gardner, CHOICE's founding editor, on page 13 of the inaugural issue, "to give brief, authoritative opinions on 2,500 to 3,000 titles per year." In keeping

\section{New Monograph Titles for 2003-04}

- CLIP 34 Marketing and Public Relations Practices in College Libraries, CLIP Note \#34, Compiled by Anita Rothwell Lindsay

m Assessing Student Learning Outcomes for Information Literacy Instruction in Academic Institutions. Elizabeth Fuselar Avery, editor

- ACRL 2002 Academic Library Trends and Statistics (3 volumes), Center for Survey Research, University of Virginia, compiler

- ACRL 2003 Academic Library Trends and Statistics (3 volumes), Library Research Center, University of Illinois at Urbana-Champaign, compiler 


\section{Year in Review}

with the times, however, $C H O I C E$ today reviews not only books but also electronic and Internet resources, materials that were unknown in 1964. In addition, $C H O I C E$ has for many years published 6,500 to 7,000 reviews annually, considerably more than originally anticipated. All told, CHOICE has published approximately 225,000 reviews during its 40 year history,

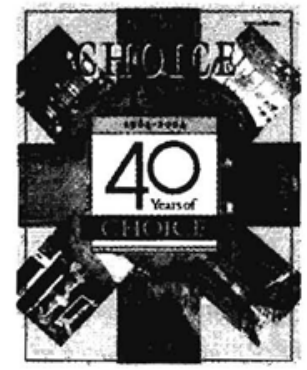
more than 105,000 of which are now available electronically via ChoiceReviews.online.

As $C H O I C E$ enters its second 40 years of publication, it is also planning for the future. In collaboration with Booklist, the ALA book review journal, $\mathrm{CHOICE}$ is developing a common platform for a new version of ChoiceReviews.online Version 2.0 (CRO2) and Booklist's first ever online product, Booklist.Online (BOL). This new state-of-the art platform will enable CHOICE and Booklist to offer separate, customizable, online products to their subscribers. In addition, the new platform will enable $C H O I C E$ and Booklist to provide their subscribers with access to each other's content, plus content from selected third parties. If all goes well, CRO2 will launch in the second or third quarter of 2005.

In another key development, in March CHOICE and ALA Editions announced their intention to publish Resources for College Libraries (RCL), a new core collection of recommended titles for academic libraries. The long-awaited successor to Books for College Libraries 3rd Edition, RCL will be an online product whose coverage includes both electronic resources and books. $\mathrm{CHOICE}$ will manage editorial development. Production, marketing, and distribution will be handled by ALA Editions. The target publication date is 2006-07.

The Project Editor for $R C L$ is Marcus Elmore, who was appointed in July. Selected from a field of highly qualified candidates, Elmore has an MLS (Southern Connecticut State University) and a Ph.D. in English Literature (Indiana) along with publishing, library science instruction, and professional library experience.

\section{ACRL Journals}

- Choice-Book review journal of ACRL; 11 issues per year (July/August combined).

- College \& Research Libraries_-Official scholarly journal of ACRL; six bimonthly issues per year.

- College \& Research Libraries News_-Official news magazine of ACRL; 11 issues per year (July/August combined).

- RBM: A Journal of Rare Books, Manuscripts, and Cultural Heritage-A journal of theory and practice covering all aspects of special collections librarianship; two issues per year. 
College \& Research Libraries News continued to publish the news of the organization, in addition to informative articles on a range of topics of interest to academic librarians. Gary Pattillo took over the editorship of the Fast Facts column from Ann Viles beginning with the September 2003 issue.

\section{$C \& R L$}

William Gray Potter of the University of Georgia Libraries was reappointed for a second three-year term as editor of $C \& R L$. The full text of journal articles going back to 1997 were placed online in a section accessible to ACRL members only. Twenty-eight articles and 36 book reviews were published in the journal during 2003-04. The journal continues to be the premier journal of scholarly communication in the field of academic librarianship, with an acceptance rate of approximately 35 percent.

\section{$R B M$}

RBM: A Journal of Rare Books, Manuscripts, and Cultural Heritage featured articles and opinion on special collections and diversity, artists' books in the curriculum, the rare book trade, cataloging medieval manuscripts in German libraries and cultural institutions and philanthropy. Full text of articles from back issues were placed on the ACRL Web site going back to Vol. 13, No. 1 of $R B M L$, with a one-year embargo on electronic publication of $R B M$ articles.

\section{ACRL Web site}

ACRL continues to spotlight important news and events on its Web site and remains a one-stop source for complete information on ACRL events and activities.

Several new members-only features have been added to the ACRL Web site in the past fiscal year. Links to dynamic rosters, which provide current information directly from the ALA membership database, have been developed for all division and section committees. An Index to Section Resources was created to provide ACRL members with comprehensive access to the many offerings available online from ACRL's 17 sections. Links to such resources as bibliographies, Webliographies, online publications, reviews, and more are included on a range of topics. The first phase of building a collection of updated and expanded Internet Resources listings for members was completed. These Web-only articles will be maintained and updated on a regular basis.

A "Meet Our Members" section has also been developed for the membership area of the site to provide prospective members with real-world examples of the impact ACRL has had on librarians. 


\section{Year in Review}

\section{Statistics}

The 2003 Academic Library Statistics project had a total number of respondents of 1,482 or 48.8 percent. The survey used the ARL survey without modification, in part to allow ARL libraries to complete the trends section only and allow ACRL to import their data directly into its database. Further, the questions on the ARL survey are modified infrequently so as to permit

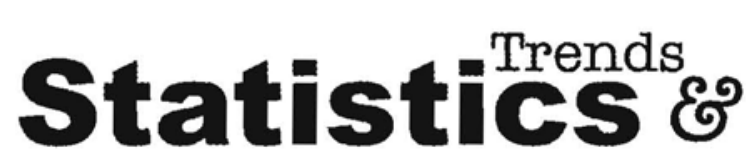
comparisons of data on a longitudinal basis across several years. The trends section used five questions that had been used previously in the 2001 survey, which looked at information literacy. The data will allow progress in assessment of information literacy programs to be measured over the two-year time frame.

As in previous years, the print publication is available in three volumes according to Carnegie classification in addition to an online electronic publication. Access is fee-based and includes searching, selection of institutions into a separate file, and display of data in tabular or graphical form to facilitate peer comparisons.

\section{Meet Our Members}

"I have been a member of ALA and ACRL for over thirty years. Those memberships and my participation in conferences have been an integral part of my professional development throughout these years. My ACRL contacts and interactions have made me a better librarian, and I hope my local experiences in a variety of situations have helped ALA and ACRL become more effective professional organizations."

-Stanton F. Biddle, Baruch College, The State University of New York

"As a person who loves asking and answering questions, I really believe librarianship is my dream job. Every reference question and every library instruction session is a unique collaboration, and I treasure the opportunities for learning and discovery they bring."

—Trina Magi, Univeristy of Vermont

To read more member comments, visit www.ala.org/acrl (click About ACRL, then Membership, and Meet our Members).

\section{Add your voice}

If you'd like to be featured on our "Meet Our Members" page, contact Mary Jane Petrowski (mpetrowski@ala.org). 


\section{ACRL Board of Directors, 2003-04}

\section{ACRL Board of Directors, 2003-04}

\section{President}

Tyrone H. Cannon, University of San Francisco

Vice-president/President-elect

Frances J. Maloy, Emory University

Past-President

Helen H. Spalding, University of Missouri - Kansas City

Budget \& Finance Committee Chair

Susan M. Allen, The Getty Research institute

\section{ACRL Councllor}

Patricia A. Wand, American University

\section{Directors-at-large}

Nancy H. Allen, University of Denver

Lois H. Cherepon, St. John's University

Deborah B. Dancik, University of Alberta

Rita Jones, City College of San Francisco

Patricia A. Kreitz, Stanford Linear Accelerator Center

W. Bede Mitchell, Georgia Southern University

Pamela Snelson, Franklin and Marshall College

Dorothy Ann Washington, Purdue University

\section{Executive Director (Ex-officio)}

Mary Ellen K. Davis, ACRLALA

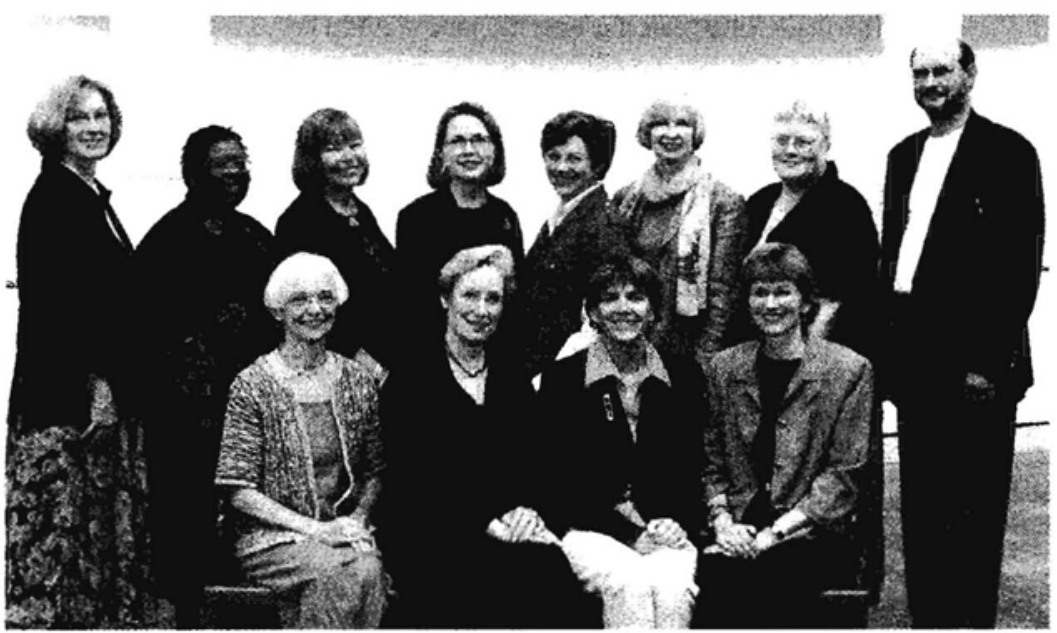

ACRL Board 2003-04 (I to r): (back) Nancy H. Allen, Dorothy Ann Washington, Pamela Snelson, Deborah B. Dancik, Patricia A. Kreitz, Susan M. Allen, Lois H. Cheperon, W. Bede Mitchell; (front) Patricia A. Wand, Helen H. Spalding, Frances J. Maloy, Mary Ellen K. Davis. Not shown: Tyrone H. Cannon, Rita Jones. 


\section{Financial Report}

\section{Susan Allen}

\section{Budget and Finance Committee Chair}

Fiscal year 2003-04 was a non-National Conference year for ACRL. As such, the budget planned for the year was expected to be negative. (This is because typically there are expenses related to the next National Conference to take place in FY05, and any revenues from the conference are deferred until the

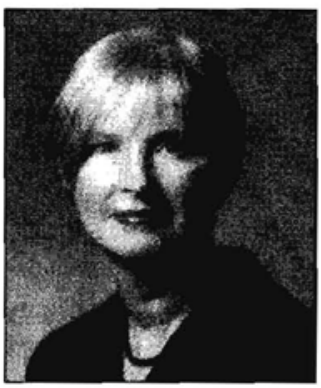
conference is held.) Accordingly, the year-end performance of the ACRL budget (without Choice) was in the negative as planned. This negative balance drew down the ACRL Operating Reserve Balance to $\$ 1,918,417$. Choice had an excess of revenues over expenses for the fiscal year, and its Ending Operating Balance was \$1,433,298.

The ACRL budget continues to show the stresses of the environment in which it functions. The association's publications are not bringing in the advertising revenues they once generated in both the areas of classified ads and product ads. Membership services continue to cost almost $50 \%$ more than the revenues generated by membership dues. Generally, ACRL's professional development activities, including Web courses, were financially successful. Staff is to be commended for holding the line on expenses so that the bottom line was less negative than actually budgeted.

\section{Dues Increase Recommended}

In order to address the long-term issue of having a significant difference between the cost of membership services and revenues from membership dues, the Budget and Finance Committee recommended a dues increase to the ACRL Board at the ALA Annual Conference in June 2004. During Board II at the 2004 Annual Conference, the ACRL Board voted to prepare a motion for a dues increase. The Board will consider this motion at the 2005 Midwinter Meeting. If the Board approves the motion it will be placed on the Spring 2005 ballot for approval by the full membership.

This is the first proposed dues increase for ACRL members in 16 years; the last time a dues increase was placed on the ballot was in 1989 . Due to the effects of inflation, it now takes $\$ 51.93$ of ACRL's dollars to purchase what ACRL could buy with $\$ 35.00$ in 1989 .

A chart showing the revenues generated by membership dues and the expenses to cover member services is on the following page. Member services include: membership promotion activities, Board and executive committee, awards, special events, sections, chapters, committees, section newsletters, liaison activities, leadership, discussion groups, standards, information literacy, scholarly communication, and the @ your library campaign. 


\section{Financial Report}

Member services revenues to expenditures

\begin{tabular}{l|ccccc} 
& $\mathbf{1 9 9 9 - 0 0}$ & $\mathbf{2 0 0 0 - 0 1}$ & $\mathbf{2 0 0 1 - 0 2}$ & $\mathbf{2 0 0 2 - 0 3}$ & $\mathbf{2 0 0 3 - 0 4}$ \\
\hline Revenues & $\$ 466,844$ & $\$ 556.977$ & $\$ 497,691$ & $\$ 514,684$ & $\$ 506,688$ \\
\hline Expenditures* & $\$ 480,563$ & $\$ 699,279$ & $\$ 590,574$ & $\$ 677,291$ & $\$ 725,022$ \\
\hline Net & $(\$ 13,719)$ & $(\$ 142,302)$ & $(\$ 92,883)$ & $(\$ 162,607)$ & $(\$ 218,334)$ \\
\hline
\end{tabular}

*Includes $\$ 25,290$ subscription equivalent subvention of C\&RL in 2003-04, $\$ 27,376$ in 2002-03, and \$2,670 in 2001-02.

\section{3-2004 operating budget highlights}

ACRL operating revenues of $\$ 1,767,667$ (excluding Choice) were $\$ 48,331$ less than budgeted revenues. This is about $39 \%$ less than last year (a National Conference year). Total ACRL expenses (excluding Choice) were $\$ 1,963,221$, which was about $12 \%$ less than budgeted and about $20 \%$ less than last year. The net ACRL revenues (excluding Choice) were -\$195,554. Included in this figure is $\$ 112,393$ for expenses for planning the National Conference. The difference of about $\$ 83,200$ was expenses not covered by dues or other revenues. Both ACRL and Choice ended FY04 in a better position than budgeted.

Choice had a particularly outstanding year, as net Choice revenues were $\$ 260,006$. Choice's total revenues were $6.24 \%$ better than budgeted while total expenses were $7.73 \%$ less than budgeted, resulting in the net, the best financial performance in years. The two major contributing factors to Choice's revenue performance were subscriptions and ad sales. However, while ad pages were thirty pages more than last year, they remained nearly one hundred pages below FY2001 levels.

\section{ACRL asset management}

In FY2004 the ACRL general endowment (Long-Term Investment Fund) eaned net interest of $\$ 23,773$. The value of ACRL's long-term investment fund as of August 31, 2004 is $\$ 1,221,440$. Choice's long-term investment fund is now valued at $\$ 533,435$. The total value of ACRL's three award endowments (Oberly, Lead, and Atkinson) is now \$138,995. At the 2004 ALA Annual Conference, the ACRL Board approved the recommendation of the Long-Term Investment Fund Task Force to begin spending the interest earned by the general endowment fund each year on strategic initiatives to be identified by the Board.

\section{4-2005 ACRL budget}

The 2004-2005 ACRL and Choice budgets, recommended by the Budget and Finance Committee, were approved at the 2004 ALA Annual Conference. Once again the ACRL budget (excluding Choice) is projected to 


\section{Financial Report}

have a deficit. The association will draw on its Operating Reserve Balance to fund member services at current levels, continuing initiatives such as scholarly communication, and programmatic needs identified through the strategic planning process. While FY2004-05 is a National Conference year, estimates of net revenue from it are conservative due to institutional reductions in support for professional development of librarians.

Thanks

I would like to publicly acknowledge and thank all of the members of the 2003-2004 ACRL Budget and Finance Committee for their efforts on behalf of ACRL. Each one of them gave a great deal of time at both the ALA Midwinter and Annual Conferences to review the budgeted and actual revenues and expenses of the association in order to knowledgeably advise the ACRL Board on fiscal matters. Committee members were: Nicholas C. Burckel, Lynn K. Chmelir, Elvernoy H. Johnson (Intern), Susan M. Kroll, Michael LaCroix, William F. Louden, Daniel R. Lee, Diane E. Perushek, Virginia Dowsing Toliver (Intern), Melissa D. Trevvett (Intern), and Sandra Yee; ex-officio members were ACRL Vice-President/President-Elect Frances J. Maloy, and ACRL Executive Director, Mary Ellen K. Davis. I also wish to thank the ACRL staff for their care in preparing budget documents and financial statements, and, in general, providing excellent support to the work of the committee. 
Financial Report

\section{Executive Summary 2003-2004}

\begin{tabular}{lrrr}
\hline SOURCES OF REVENUE & $\begin{array}{r}\text { FY2003 } \\
\text { ACTUAL }\end{array}$ & $\begin{array}{r}\text { FY2004 } \\
\text { BUDGET }\end{array}$ & $\begin{array}{r}\text { FY2004 } \\
\text { ACTUAL }\end{array}$ \\
\hline Operating Reserve Fund & $\$ 1,872,331$ & $\$ 2,213,971$ & $\$ 2,213,971$ \\
Long-Term Investment Fund & $\$ 987,691$ & $\$ 1,167,860$ & $\$ 1,167,860$ \\
CHOICE Operating Reserve Fund & $\$ 1,195,494$ & $\$ 1,173,291$ & $\$ 1,173,290$ \\
CHOICE Long-Term Investment Fund $\$ 461,458$ & $\$ 511,286$ & $\$ 511,286$ \\
\hline Subtotal & $\$ 4.516 .974$ & $\$ 5,066,408$ & $\$ 5,066,408$ \\
\hline
\end{tabular}

\begin{tabular}{lrrr} 
MEMBERSHIP DUES AND OTHER & & & \\
Dues & $\$ 459,010$ & $\$ 424,515$ & $\$ 457,402$ \\
Other (e.g., standards) & $\$ 10,173$ & $\$ 3,500$ & $\$ 5,977$ \\
Donations & $\$ 15,500$ & $\$ 3,000$ & $\$ 16,190$ \\
Awards & $\$ 19,200$ & $\$ 9,400$ & $\$ 20,258$ \\
Section Newsletters & $\$ 1,600$ & $\$ 1,200$ & $\$ 600$ \\
Special Events & $\$ 16,026$ & $\$ 26,300$ & $\$ 6,261$ \\
\hline Subtotal & $\$ 521,509$ & $\$ 467,915$ & $\$ 506,688$ \\
\hline & & & \\
PUBLICATIONS & & & $\$ 2,516,971$ \\
CHOICE & $\$ 2,283,116$ & $\$ 2,369,093$ & $\$ 144,231$ \\
C\&RL & $\$ 145,093$ & $\$ 154,939$ & $\$ 409,595$ \\
C\&RL News & $\$ 436,101$ & $\$ 445,940$ & $\$ 26,762$ \\
RBM & $\$ 30,830$ & $\$ 34,597$ & $\$ 111,920$ \\
Nonperiodical Publications & $\$ 101,394$ & $\$ 128,400$ & $\$ 88,646$ \\
\hline Library Statistics & $\$ 60,617$ & $\$ 101,525$ & $\$ 3,298,125$ \\
\hline Subtotal & $\$ 3,057,151$ & $\$ 3,234,494$ & \\
\hline
\end{tabular}

\section{EDUCATION}

Regional Institutes

National Conference $(2003,2005) \$ 1,314,370$

Pre-Conferences \& Workshops \$94,091

Web-CE

$\$ 27,974$

WESS - Paris Conference

Subtotal

$\$ 1,614,605$

$\$ 218,379$

$(\$ 12,675)$

$\$ 127,278$

$\$ 56,000$

$\$ 93,700$

$\$ 482,682$

$\$ 178,709$

$(\$ 12,000)$

$\$ 167,525$

$\$ 64,704$

$\$ 80,887$

$\$ 479,825$

\section{SPECIAL PROGRAMS \\ Friends of ACRL-Restricted \\ Friends of ACRL-Operating}

$$
\begin{array}{r}
\$ 8,020 \\
\$ 0
\end{array}
$$

$\$ 10,000$

$\$ 5,770$

$\$ 0$

$\$ 0$

\begin{tabular}{lrrr}
\hline TOTAL REVENUE & $\$ 5,193,265$ & $\$ 4,185,091$ & $\$ 4,284,637$ \\
CHOICE Revenue & $\$ 2,283,116$ & $\$ 2,369,093$ & $\$ 2,516,971$ \\
TOTAL REV. W/O CHOICE & $\$ 2,910,148$ & $\$ 1,815,998$ & $\$ 1,767,667$ \\
National Conference Revenue & $\$ 1,314,370$ & $(\$ 12,675)$ & $(\$ 12,000)$ \\
TotalRev.W/ONational Conference $\$ 1.595,778$ & $\$ 1.828 .673$ & $\$ 1.779 .667$ \\
\hline
\end{tabular}

Note: Actual numbers shown are rounded from two decimal places. Therefore, subtotals may not precisely represent column totals due to rounding. 


\begin{tabular}{|c|c|c|c|}
\hline OBJECT OF EXPENSE & $\begin{array}{l}\text { FY2003 } \\
\text { ACTUAL }\end{array}$ & $\begin{array}{l}\text { FY2004 } \\
\text { BUDGET }\end{array}$ & $\begin{array}{l}\text { FY2004 } \\
\text { ACTUAL }\end{array}$ \\
\hline \multicolumn{4}{|l|}{ MEMBERSHIP ACTIVITIES } \\
\hline Membership Services & $\$ 31,616$ & $\$ 62,854$ & $\$ 68,324$ \\
\hline Exec. Comm. \& Board & $\$ 108,104$ & $\$ 171,843$ & $\$ 180,036$ \\
\hline Advisory & $\$ 52,631$ & $\$ 10,586$ & $\$ 48,811$ \\
\hline Standards Distribution & $\$ 7,199$ & $\$ 10,171$ & $\$ 11,807$ \\
\hline Discussion Groups & $\$ 3,652$ & $\$ 4,255$ & $\$ 2,033$ \\
\hline Awards & $\$ 37,555$ & $\$ 21,544$ & $\$ 38,120$ \\
\hline Chapters & $\$ 36,248$ & $\$ 66,600$ & $\$ 21,020$ \\
\hline Committees & $\$ 44,838$ & $\$ 40,380$ & $\$ 50,872$ \\
\hline Sections & $\$ 95,133$ & $\$ 91,278$ & $\$ 126,000$ \\
\hline Section Newsletters & $\$ 30,908$ & $\$ 32,714$ & $\$ 29,788$ \\
\hline$C \& R L$ Over Revenue & $\$ 27,376$ & $\$ 39,667$ & $\$ 25,290$ \\
\hline C\&RL News Over Revenue & $\$ 0$ & $\$ 0$ & $\$ 0$ \\
\hline Liaisons to Higher Ed. Organizations & $\$ 35,319$ & $\$ 46,421$ & $\$ 42,648$ \\
\hline Special Events & $\$ 16,014$ & $\$ 24,929$ & $\$ 12,196$ \\
\hline Information Literacy & $\$ 11,757$ & $\$ 36,465$ & $\$ 5,314$ \\
\hline Scholarly Communication & $\$ 57,310$ & $\$ 73,429$ & $\$ 27,978$ \\
\hline @ Your Library & $\$ 3,876$ & $\$ 24,215$ & $\$ 19,807$ \\
\hline Scholarships & $\$ 77,755$ & $\$ 15,000$ & $\$ 14,980$ \\
\hline Subtotal & $\$ 677,291$ & $\$ 772,351$ & $\$ 725,022$ \\
\hline \multicolumn{4}{|l|}{ SPECIAL PROJECTS } \\
\hline Friends of ACRL-Operating & $\$ 3,915$ & $\$ 5,821$ & $\$ 6,025$ \\
\hline Friends of ACRL-Restricted & $\$ 6,825$ & $\$ 10,000$ & $\$ 0$ \\
\hline Subtotal & $\$ 10,740$ & $\$ 15,821$ & $\$ 6,025$ \\
\hline \multicolumn{4}{|l|}{ PUBLICATIONS } \\
\hline CHOICE & $\$ 2,275,320$ & $\$ 2,446,129$ & $\$ 2,256,965$ \\
\hline$C \& R L$ & $\$ 145,093$ & $\$ 154,939$ & $\$ 144,231$ \\
\hline C\&RL News & $\$ 344,127$ & $\$ 439,082$ & $\$ 374,018$ \\
\hline$R B M$ & $\$ 32,755$ & $\$ 39,393$ & $\$ 27,199$ \\
\hline Nonperiodical Publications & $\$ 70,202$ & $\$ 115,827$ & $\$ 110,633$ \\
\hline Library Statistics & $\$ 76,228$ & $\$ 88,190$ & $\$ 88,822$ \\
\hline Subtotal & $\$ 2,943,725$ & $\$ 3,283,560$ & $\$ 3,001,868$ \\
\hline \multicolumn{4}{|l|}{ EDUCATION } \\
\hline Regional Institutes & $\$ 152,283$ & $\$ 214,223$ & $\$ 146,657$ \\
\hline National Conference $(2003,2005)$ & $\$ 840,016$ & $\$ 161,139$ & $\$ 100,393$ \\
\hline Pre-Conferences \& Workshops & $\$ 86,644$ & $\$ 122,444$ & $\$ 140,609$ \\
\hline Web-CE & $\$ 24,128$ & $\$ 30,493$ & $\$ 34,923$ \\
\hline WESS - Paris Conference & $\$ 15,827$ & $\$ 90,404$ & $\$ 64,689$ \\
\hline Subtotal & $\$ 1,118,899$ & $\$ 618,703$ & $\$ 487,270$ \\
\hline TOTAL EXPENSES & $\$ 4,743,829$ & $\$ 4,680,435$ & $\$ 4,220,185$ \\
\hline CHOICE EXPENSES & $\$ 2,275,320$ & $\$ 2,446,129$ & $\$ 2,256,965$ \\
\hline TOTAL EXP. W/O CHOICE & $\$ 2,468,508$ & $\$ 2,234,306$ & $\$ 1,963,221$ \\
\hline Net W/O CHOICE & $\$ 441,640$ & $(\$ 418,308)$ & $(\$ 195,554)$ \\
\hline CHOICE Net & $\$ 7,796$ & $(\$ 77,036)$ & $\$ 260,006$ \\
\hline Added to CHOICE LTI & $(\$ 30,000)$ & $\$ 0$ & $\$ 0$ \\
\hline CHOICE Ending Operating BaI & $\$ 1,173,291$ & $\$ 1,096,255$ & $\$ 1,433,298$ \\
\hline Added to ACRL LTI & $(\$ 100,000)$ & $(\$ 100,000)$ & $(\$ 100,000)$ \\
\hline Ending ACRL oper. reserve balance & $\$ 2,213,971$ & $\$ 1,695,663$ & $\$ 1,918,417$ \\
\hline Mandated Operating Reserve & $\$ 502,818$ & $\$ 533,028$ & $\$ 533,028$ \\
\hline TOTAL EXP. W/O NTL CNF & $\$ 1,628,493$ & $\$ 2,073,167$ & $\$ 1,862,828$ \\
\hline
\end{tabular}




\section{Friends of ACRL}

The Friends of ACRL donations support areas key to ACRL's mission. These include the Professional Development Scholarship Fund, Innovative New Program Fund, Best Practices in Academic Librarianship Fund, and Global Connec-

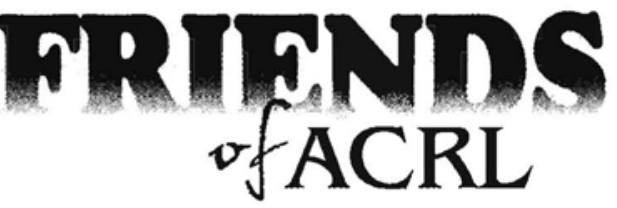
tion Fund.

Since the establishment of the Friends of ACRL, 107 donors have become Friends and contributed more than $\$ 38,000$ to demonstrate their support for its initiatives. Money from the Friends Funds has been used to provide scholarships for ACRL professional development activities and to support the ACRL Awards Program through publicity and the creation of special presidential awards.

Thanks to those listed below for contributing to the Friends of ACRL in 2003-04.

$\begin{array}{cc}\text { MILLENNIUM CLUB } \\ \text { Tom Kirk } & \text { Hannelore B. Rader }\end{array}$

GOLD CLUB

Patricia Senn Breivik

SILVER CLUB

Larry Hardesty

Pamela Snelson

Althea Jenkins

\section{Century Club}

Nancy H. Allen

Susan M. Allen

Janis M. Bandelin

Stephen J. Bell

Susan Brynteson

John M. Budd

Mary Ellen Davis

Elaine K. Didier

Julia Gelfand

Patricia A. Kreitz
Michael J. LaCroix

Frances Maloy

Greta McKelvey

W. Bede Mitchell

William N. Nelson

John and Aracely Pollitz

Sharon Rogers

Helen H. Spalding

Dorothy Ann Washington

\section{FRIENDS}

Donald G. Frank

J. Paul Getty Trust

Lee Hisle

Mary Jane Petrowski

Ann M. Tenglund 
Many of you have had phone and/or e-mail contact with ACRL's staff, of which there are 13.35 ALA-approved FTE positions at headquarters. Here's your chance to put a face with that voice or e-mail signature. Below is a listing of current ACRL staff (including two of ACRL's Choice 22.4 FTE staff) with information about their responsibilities. Take a minute to "meet the staff?" We're looking forward to hearing from you.

ACRL'S office hours are 8:30 a.m. to 4:30 p.m. (CST), Monday through Friday. All ALA staff have direct telephone lines. All prefixes are (312) $280-$, followed by the four-digit extension. If you use the toll-free number (800-545-2433) you will be instructed to enter the extension of the person you wish to speak to.
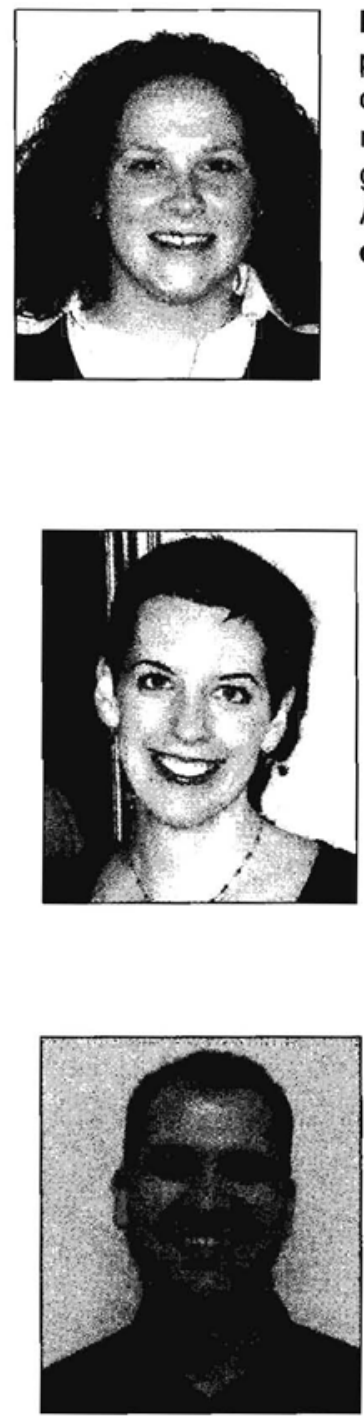

MEGAN BIELEFELD, program coordinator. Prepares ACRL's ballots for the ALA annual elections; coordinates ACRL awards program, chapters, press releases and promotional activities, and ACRL programs at the ALA Annual Conference. Contact for ACRL discussion groups. Phone: (312) 280-2514; e-mail: mbielefeld@ala.org

MARGOT SUTTON CONAHAN, manager of professional development. Manages all aspects of ACRL's professional development offerings, including the ACRL National Conference, preconferences, workshops, institutes, and seminars. Phone: (312) 280-2522; e-mail: msutton@ala. org

DAVID CONNOLLY, program officer. Manages ACRL's divisional appointment activities; coordinates activities of Board of Directors (agenda and document preparation for Board meetings, travel, etc.); assists in budget preparation; prepares and maintains financial reports for ACRL; receives contributions from corporate sponsors and maintains records for ACRL; manages ACRL's office. Phone: (312) 280-2519; e-mail: dconnolly@ala.org 
Meet the ACRL Staff

MARY ELLEN K. DAVIS, executive director. Directs activities of the ACRL and CHOICE offices. Coordinates policy implementation and prepares ACRL's budgets. Ex-officio to the ACRL Executive committee and the Board of Directors. Serves as official contact for higher education organizations and coordinates ACRL Colleagues, Information Literacy, and Scholarly Communication programs. Phone: (312) 280-3248; e-mail: mdavis @ala. org

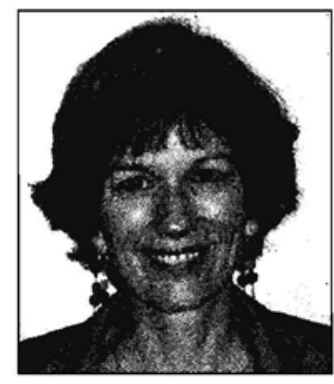

ANN-CHRISTE GALLOWAY, production editor. Copyedits and lays out C\&RL News in print and online. Writes "People in the News" and "Grants and Acquisitions" for C\&RL News. Phone: (312) 280-2524; e-mail: agalloway@ala.org

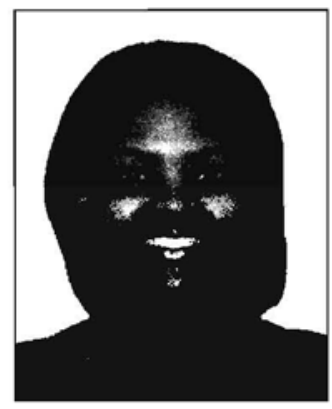

FRANCINE GRAF, managing editor of Choice. Manages all aspects of the magazine, reviewson-cards, and electronic databases; coordinates the work of Choice's editorial staff; plans the editorial calendar; handles Choice's business and economics sections. Phone: (860) 347-6933; e-mail: fgraf@ala-choice.org

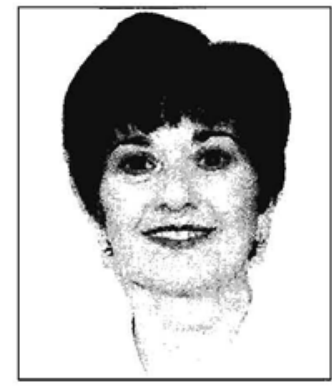

DAWN MUELLER, production editor. Maintains ACRL's Web site; lays out and produces $C \& R L$; designs and produces $R B M$; works with section editors to produce and distribute section newsletters; designs and produces ACRL brochures and flyers. Phone: (312) 280-2516; e-mail: dmueller@ala.org

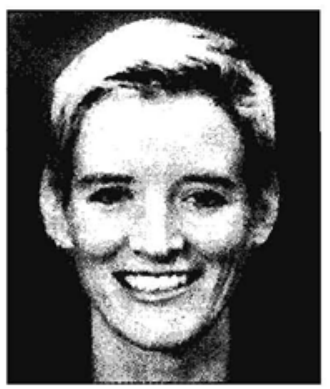




\section{Meet the ACRL Staff}
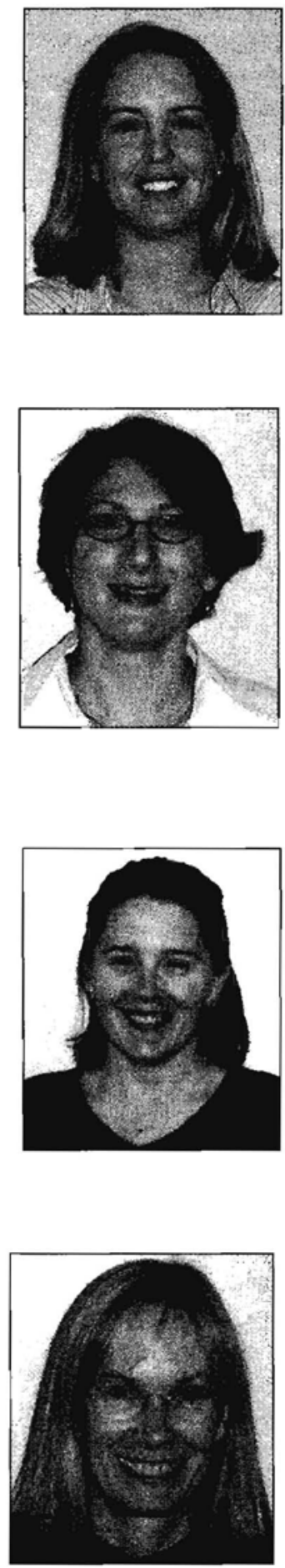

TORY EDWARDS ONDRLA, meeting planner. Manages logistics for ACRL professional development events, including preconferences, workshops, institutes, and the ACRL National Conference. Phone: (312) 280-2515; e-mail: tedwards@ala.org

STEPHANIE ORPHAN, editor-in-chief, $C \& R L$ News/Web developer. Conceptualizes, develops and implements new products and services to be delivered over the Web; responsible for content and production of C\&RL News in print and online; oversees development of the ACRL Web site. Phone: (312) 280-2511; e-mail: sorphan@ala. org

ELISE PARKER, classified ads manager/editorial assistant. Manages job ads for C\&RL News in print and online; contact for information about subscriptions, job ads, and manuscript submissions for C\&RL News; designs and produces ACRL brochures and flyers. Phone: (312) 2802513; fax: (312) 280-7663; e-mail: eparker@ ala.org

MARY JANE PETROWSKI, associate director. Serves as chief operating officer for ACRL; coordinates ACRL membership promotion and retention activities; coordinates Friends of ACRL; oversees ACRL's Annual Conference programs and activities; coordinates activities of sections and chapters; manages section appointments and nominations processes. Phone: (312) 280-2523; e-mail: mpetrowski@ ala.org 


\section{Meet the ACRL Staff}

IRVING ROCKWOOD, editor and publisher of Choice. Serves as editor and publisher of Choice. Handles magazine and other product advertising sales, subscription services, and marketing and promotions for Choice and ACRL serial publications. Phone: (860) 347-6933; e-mail: irockwood@ala-choice.org

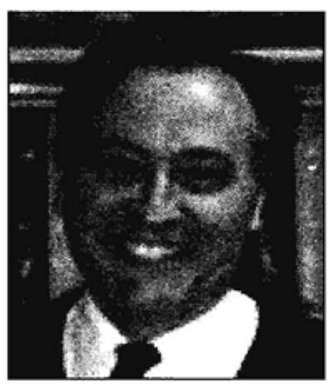

HUGH THOMPSON, manager of publications. Handles all questions about ACRL's publications; oversees production of C\&RL and RBM; answers questions about ACRL's Web site; manages ACRL's Academic Libraries Trends and Statistics program. Phone: (312) 280-2517; e-mail: hthompson@ala.org

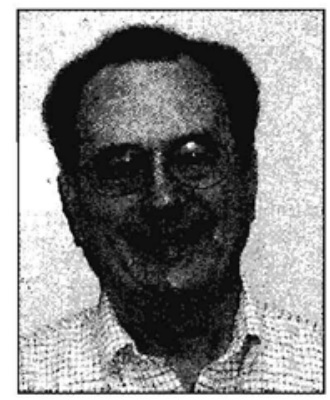

